\title{
Optimization of Zeaxanthin Production by Immobilized Flavobacterium sp. Cells in Fluidized Bed Bioreactor
}

\author{
Ma Del Carmen Chávez-Parga ${ }^{1}$, Alejandro Munguía-Franco², \\ Mayanin Aguilar-Torres ${ }^{2}$, Eleazar M. Escamilla-Silva ${ }^{{ }^{*}}$ \\ ${ }^{1}$ Division de Estudios de Posgrado, Facultad de Ingeniería Química, Universidad Michoacana de San Nicolas de Hidalgo, \\ Morelia, Mexico \\ ${ }^{2}$ Laboratorio de Biotecnologia y Bioingenieria, Departamento de Ingenieria Quimica, Instituto Tecnologico de Celaya, \\ Celaya, Mexico \\ Email: *eleazar@iacelaya.itc.mx
}

Received September 23, 2012; revised October 28, 2012; accepted November 13, 2012

\begin{abstract}
From time immemorial, human beings have used pigments made from vegetables, fruits, superior plants, animal tissues and cereals. One of the greatest sources of pigments is the bacterium that, with the use of the modern technology, has increased the production of metabolites of interest. The microbiological production of carotenoids has not been optimized to obtain pigment production quantities of pigments and carotenoids recovery that lower production costs. The aim of this work was to design a Zeaxanthin production process with Flavobacterium sp. immobilized cells in a fluidized bed bioreactor. An optimum culture medium for Zeaxanthin production in stirred flasks $\left(2.46 \mathrm{~g} \cdot \mathrm{L}^{-1}\right)$ was obtained. Furthermore, optimum process conditions for a maximum yield of Zeaxanthin production, by fluidized bed bioreactor, were established. A statistical analysis showed that the most significant factors were air flow, $\mathrm{pH}$ and $\mathrm{NaCl}$ concentration $\left(4.5 \mathrm{~g} \cdot \mathrm{L}^{-1}\right)$. In this study a maximum Zeaxanthin production of $3.8 \mathrm{~g} \cdot \mathrm{L}^{-1}$ was reached. The highest reported yield to date was $0.329 \mathrm{~g} \cdot \mathrm{L}^{-1}$.
\end{abstract}

Keywords: Fluidized Bed Bioreactor; Orthogonal Design; Flavobacterium sp.; Zeaxanthin

\section{Introduction}

More than 600 carotenoid structures are known, however, their availability is very limited. Only 8 of them have been used [1]. Carotenoids are natural pigments synthesized by plants and microorganisms as hydrocarbons (carotenes) and their oxygenated derivatives or oxycarotenoids (xanthophylls). Bacteria, especially Flavobacterium synthesize Zeaxanthin $(90 \%$ - 95\%). The main carotenoids function is protection against free radicals [2]. The protective function depends upon the chemical structure, which can differ in the chain and in the presence of the cyclic chromophore [3]. Xanthophylls are responsible for the colour of egg yolks, feathers and birds skin, especially Zeaxanthin (orange-yellow pigment), hence their use in the formulation of poultry diets [4]. Furthermore, there is evidence that xanthophylls, especially Zeaxanthin and Lutein, have a relevant function in preventing cardiovascular and ophthalmological diseases, as well as different types of cancer (colon, oesophagus, etc.) [5].

"Corresponding author.
Industry uses them as nutritional supplements, in pharmaceuticals, food colorants, and animal diets [6]. Most of the carotenoids used industrially are chemically synthesized (e.g.: Astaxanthin, Cantaxanthin, Zeaxanthin and $\beta$-carotene). Nowadays the world tendency is to return to natural products [7]. Therefore, the production of natural pigments has assumed great importance. One of the greatest sources is the bacterium that, with the use of the modern technology, has increased the production of metabolites of interest. The microbiological production of carotenoids has not been optimized to obtain amounts of production of pigments and recovery of carotenoids that lower costs of the production. The objective of the present work was to establish a process for the production of Zeaxanthin using immobilized cells of Flavobacterium sp. in a fluidized bioreactor.

\section{Materials and Methods}

\subsection{Microorganism}

Flavobacterium sp. ATCC 21588 conserved in soy tripticasein slants at $4^{\circ} \mathrm{C}$ and subcultured every two months was used in this work. 


\subsection{Culture Medium}

Inoculum preparation. Flavobacterium sp. was grown on tripticasein soy agar for two days. The colonies were then suspended in a saline solution $\left(4.5 \mathrm{~g} \cdot \mathrm{L}^{-1}\right)$. This suspension was used to inoculate Erlenmeyer flasks (500 $\mathrm{mL}$ ) that contained $250 \mathrm{~mL}$ of minimal media, $\mathrm{pH} 7.2$. Flavobacterium sp. was grown at $27^{\circ} \mathrm{C}$ and $250 \mathrm{rpm}$ in a radial shaker for $56 \mathrm{~h}$. In preliminary experiments the effects of different glucose concentrations as well as other nutrients were studied. The nutrients and concentrations studied were: 10,20 and $30 \mathrm{~g} \cdot \mathrm{L}^{-1}$ glucose; 3,5 and $7 \mathrm{~g} \cdot \mathrm{L}^{-1}$ corn steep liquor; 0.01, 0.05 and $0.1 \mathrm{M} \mathrm{ZnSO}_{4}$; 1,3 and $5 \mathrm{~g} \cdot \mathrm{L}^{-1} \mathrm{NH}_{4} \mathrm{Cl} ; 3,5$ and $8 \mathrm{~g} \cdot \mathrm{L}^{-1} \mathrm{KH}_{2} \mathrm{PO}_{4} ; 1,1.5$ and $2 \mathrm{~g} \cdot \mathrm{L}^{-1} \mathrm{MgSO}_{4} ; 0.01,0.05$ and $0.1 \mathrm{M} \mathrm{FeSO}_{4} ; 0.01$, 0.05 and $0.1 \mathrm{M} \mathrm{MnSO}_{4} ; 0.01,0.05$ and $0.1 \mathrm{M} \mathrm{CoCl}_{2}$. These experiments were done in Erlenmeyer flasks (500 $\mathrm{mL})$, inoculated with Flavobacterium sp. suspension (5\%, $\mathrm{v} / \mathrm{v}$ ) without $\mathrm{pH}$ adjustment, incubated at $27^{\circ} \mathrm{C}$ and 250 rpm in a radial shaker for $56 \mathrm{~h}$ and according experimental design $\mathrm{L}_{18}$ (Table 1).

\subsection{Immobilization of Flavobacterium sp. Cells}

A modification of method of Montes and Magaña [8] was used for cell immobilization. Under sterile conditions a mixture $(1: 1)$ of Flavobacterium sp. suspension and poligaracturonic acid solution $(8 \% \mathrm{w} / \mathrm{v})$ was prepared. The mixture was homogenized in a mixer (Osterizer junior of $230 \mathrm{~mL}$ at $100 \mathrm{rpm}$ ) for $10 \mathrm{~min}$. The solution was adjusted with polygalacturonic acid to a final concentration of $4 \%$. The mixture was forced through a multi-needle template (gauge 21 for $3 \mathrm{~mm}$ beads) with a peristaltic pump (CRODE, Mexico) flowing at 10 $\mathrm{mL} \cdot \mathrm{min}^{-1}$ and droplets were collected in a sterile $3.5 \%$ $\mathrm{CaCl}_{2}$ solution. After soaking for $3 \mathrm{~h}$ the liquid was decanted and spherical beads were washed with sterile distilled $\mathrm{H}_{2} \mathrm{O}$ and stored at $4^{\circ} \mathrm{C}$ for $24 \mathrm{~h}$. The diameter of beads was measured in a microscope (Leica, LMDS) with a micrometer grid. Pellets of 1 and $3 \mathrm{~mm}( \pm 0.13)$ were selected and tested for the production of Zeaxanthin.

\subsection{Fluidized Bed Bioreactor}

An orthogonal experimental design $\mathrm{L}_{8}\left(3^{4}\right)$ with one replica $[9,10]$ was used to investigate effects of temperature, $\mathrm{pH}$, air flow, natural light, diameter of pellet, $\mathrm{NaCl}$ addition and inoculum concentration on Zeaxanthin produc-

Table 1. Zeaxanthin production at $56 \mathrm{~h}$ of fermentation in shake flask. $\mathrm{L}_{18}$ orthogonal experiment design.

\begin{tabular}{|c|c|c|c|c|c|c|c|c|c|}
\hline \multirow{2}{*}{ Experiment No. } & \multicolumn{9}{|c|}{ FACTORS $^{\mathrm{a}}$} \\
\hline & A Molar & B $g \cdot L^{-1}$ & $\mathbf{C g} \cdot \mathrm{L}^{-1}$ & $\mathbf{D} \mathrm{g} \cdot \mathrm{L}^{-1}$ & $\mathbf{E} \mathrm{g} \cdot \mathrm{L}^{-1}$ & $\mathbf{F ~ g} \cdot \mathrm{L}^{-1}$ & G Molar & H Molar & Zeaxanthin (mg/mL) \\
\hline $8^{b}$ & 0.01 & 30 & 5 & 5 & 5 & 1 & 0.1 & 0.01 & 2.426 \\
\hline 11 & 0.05 & 10 & 5 & 1 & 3 & 2 & 0.1 & 0.05 & 0.359 \\
\hline 7 & 0.01 & 30 & 3 & 3 & 3 & 2 & 0.05 & 0.1 & 1.059 \\
\hline 13 & 0.05 & 20 & 3 & 3 & 8 & 1 & 0.1 & 0.05 & 1.834 \\
\hline 10 & 0.05 & 10 & 3 & 5 & 8 & 1.5 & 0.05 & 0.01 & 0.912 \\
\hline 16 & 0.05 & 30 & 3 & 5 & 5 & 2 & 0.01 & 0.05 & 1.247 \\
\hline 3 & 0.01 & 10 & 7 & 5 & 8 & 2 & 0.1 & 0.1 & 0.160 \\
\hline 14 & 0.05 & 20 & 5 & 5 & 3 & 1.5 & 0.01 & 0.1 & 0.463 \\
\hline 5 & 0.01 & 20 & 5 & 3 & 8 & 2 & 0.01 & 0.01 & 0.543 \\
\hline 9 & 0.01 & 30 & 7 & 1 & 8 & 1.5 & 0.01 & 0.05 & 0.936 \\
\hline 17 & 0.05 & 30 & 5 & 1 & 8 & 1 & 0.05 & 0.1 & 0.726 \\
\hline 1 & 0.01 & 10 & 3 & 1 & 3 & 1 & 0.01 & 0.01 & 0.725 \\
\hline 15 & 0.05 & 20 & 7 & 1 & 5 & 2 & 0.05 & 0.01 & 1.370 \\
\hline 2 & 0.01 & 10 & 5 & 3 & 5 & 1.5 & 0.05 & 0.05 & 1.058 \\
\hline 12 & 0.05 & 10 & 7 & 3 & 5 & 1 & 0.01 & 0.1 & 0.566 \\
\hline 6 & 0.01 & 20 & 7 & 5 & 3 & 1 & 0.05 & 0.05 & 0.357 \\
\hline 4 & 0.01 & 20 & 3 & 1 & 5 & 1.5 & 0.1 & 0.1 & 1.599 \\
\hline 18 & 0.05 & 30 & 7 & 3 & 3 & 1.5 & 0.1 & 0.01 & 0.549 \\
\hline
\end{tabular}

${ }^{\mathrm{a}} \mathrm{A}=$ Zinc sulfate heptahydrated, $\mathrm{B}=$ Dextrose, $\mathrm{C}=$ Corn steep liquor, $\mathrm{D}=$ Ammonium chloride, $\mathrm{E}=$ Potassium hydrogen phosphate, $\mathrm{F}=\mathrm{Magnesium}$ sulfate heptahydrated, $\mathrm{G}=$ Ferrous sulfate heptahydrated-Cobalt chloride hexahydrated, $\mathrm{H}=$ Manganese sulphate monohydrate. ${ }^{\mathrm{b}}$ Experimental treatment which had the highest concentration of Zeaxanthin. 
tion (Table 2). Two 3.5 L bioreactors (CRODE, Mexico) were used in a random sequence Figure 1).

In experimental design, orthogonal means balanced, separable, not mixed or confounded. The symbol $\mathrm{L}_{\mathrm{a}}\left(\mathrm{b}^{\mathrm{c}}\right)$ is used to represent the orthogonal array where "a" is the number of experimental runs. "b" the number of levels

Table 2. Orthogonal experimental design $\mathrm{L}_{8}\left(2^{3}\right)$ with one replica, used to evaluate the effects of air flux, $\mathrm{pH}$, temperature, pellet diameter, inoculum concentration, presence of natural light and sodium chloride addition on Zeaxanthin production*.

\begin{tabular}{|c|c|c|c|c|c|c|c|c|}
\hline Experiment & $\begin{array}{l}\text { Air flow } \\
\text { (vvm) }\end{array}$ & $\mathrm{pH}$ & $\begin{array}{l}\text { Temperature } \\
\left({ }^{\circ} \mathrm{C}\right)\end{array}$ & $\begin{array}{l}\text { Bead diameter } \\
(\mathrm{mm})\end{array}$ & $\begin{array}{c}\text { Inoculum } \\
\text { concentration \% }\end{array}$ & $\begin{array}{l}\text { Presence of } \\
\text { natural light }\end{array}$ & $\begin{array}{l}\text { Saline } \\
\text { solution }\end{array}$ & $\begin{array}{l}\text { Average Zeaxanthin } \\
\text { production }\left(g \cdot \mathrm{L}^{-1}\right)\end{array}$ \\
\hline 1 & 3 & 5.2 & 30 & 3 & 10 & No & No & 2.29 \\
\hline 2 & 5 & 5.2 & 27 & 1 & 10 & Yes & No & 1.25 \\
\hline 3 & 3 & 5.2 & 30 & 3 & 5 & Yes & Yes & 2.18 \\
\hline 4 & 3 & 7.2 & 27 & 1 & 5 & No & No & 1.4 \\
\hline 5 & 5 & 7.2 & 30 & 3 & 5 & Yes & No & 1.25 \\
\hline 6 & 5 & 7.2 & 30 & 1 & 10 & No & Yes & 1.33 \\
\hline 7 & 5 & 5.2 & 27 & 3 & 5 & No & Yes & 2.3 \\
\hline 8 & 3 & 7.2 & 27 & 3 & 10 & Yes & Yes & 2.96 \\
\hline
\end{tabular}

*Culture medium contained the following (per liter): $10 \mathrm{~g}$ dextrose, $5 \mathrm{~g}$ corn steep liquor, $5 \mathrm{~g} \mathrm{NH}_{4} \mathrm{Cl}, 8 \mathrm{~g} \mathrm{KH}_{2} \mathrm{PO}_{4}, 1.5 \mathrm{~g} \mathrm{MgSO}_{4}$ besides $0.05 \mathrm{M} \mathrm{ZnSO}_{4}, 0.05 \mathrm{M}$ $\mathrm{FeSO}_{4}, 0.01 \mathrm{M} \mathrm{MnSO}_{4}$, and $0.05 \mathrm{M} \mathrm{CoCl}_{2}$.

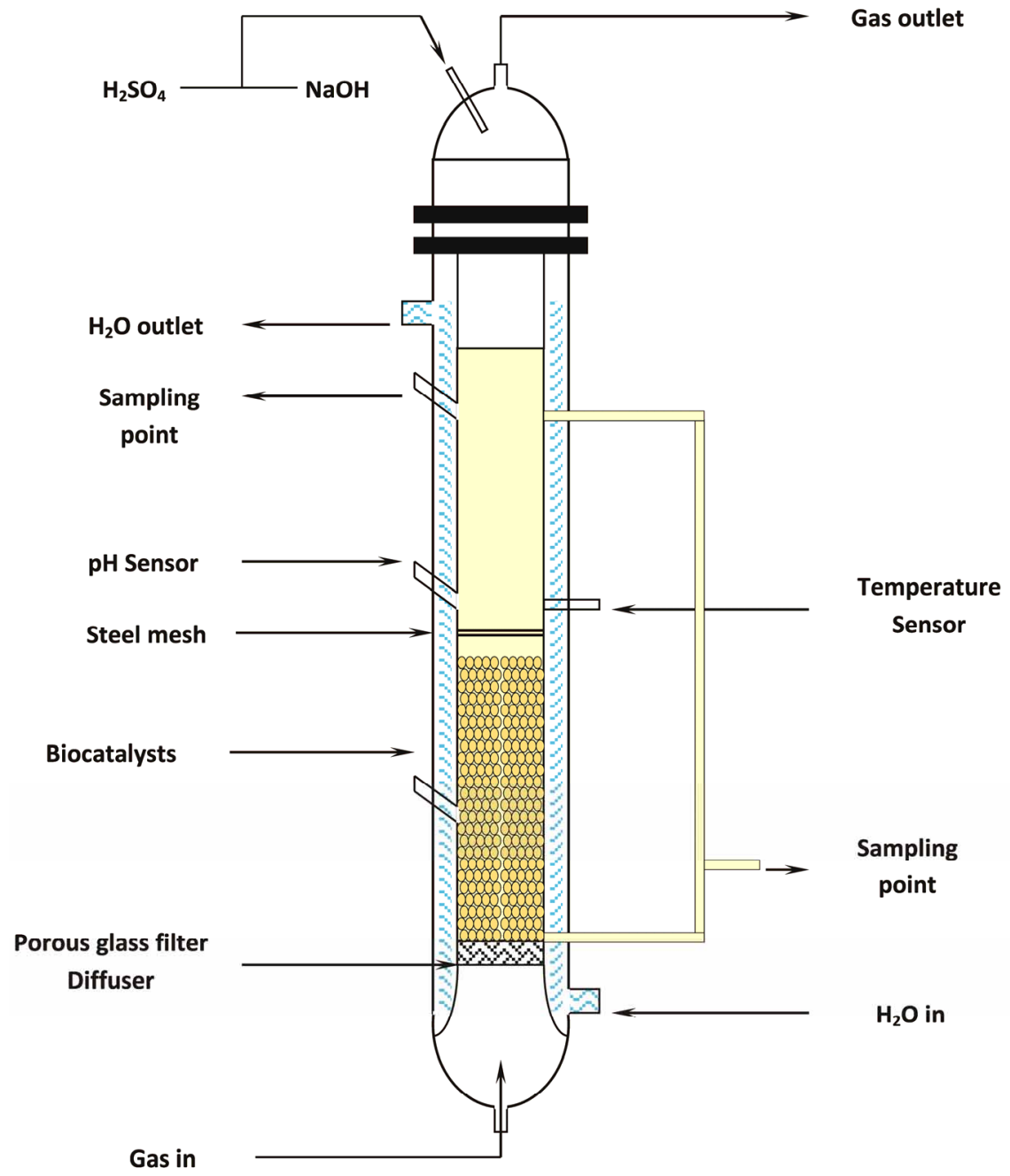

Figure 1. Fermentation system. 
for each factor or variable and "c" the number of factors investigated. Glucose concentration was $10 \mathrm{~g} \cdot \mathrm{L}^{-1}$, corn steep liquor $5 \mathrm{~g} \cdot \mathrm{L}^{-1}, \mathrm{ZnSO}_{4} 0.05 \mathrm{M}, \mathrm{NH}_{4} \mathrm{Cl} 5 \mathrm{~g} \cdot \mathrm{L}^{-1}$, $\mathrm{KH}_{2} \mathrm{PO}_{4} 8 \mathrm{~g} \cdot \mathrm{L}^{-1}, \mathrm{MgSO}_{4} 1.5 \mathrm{~g} \cdot \mathrm{L}^{-1}, \mathrm{FeSO}_{4} 0.05 \mathrm{M}$, $\mathrm{MnSO}_{4} 0.01 \mathrm{M}$, and $\mathrm{CoCl}_{2} 0.05 \mathrm{M} .4 .5 \mathrm{~g} \cdot \mathrm{L}^{-1}$ of $\mathrm{NaCl}$ was added because it presented a positive effect in the Zeaxanthin production.

Since Flavobacterium sp. began to produce Zeaxanthin above 5, the pH's treated were 4.2 and 7.2. The culture media were sterilized in situ and the immobilized cells were added $8095( \pm 845)$ pellets per batch and each pellet had a wet weight of $1.15 \times 10^{-4} \mathrm{~g}$ cells so that approximately a total of $0.93 \mathrm{~g}$ of cells was added. Aeration rates of 1 and 3 volumes of air per volume of medium per minute (vvm) were used to maintain the fluidized state. During the cultivation of $56 \mathrm{~h}$ at $27^{\circ} \mathrm{C}$, sterile $\mathrm{H}_{2} \mathrm{O}$ was added at $8 \mathrm{~h}$ intervals to compensate for evaporation loss while $\mathrm{pH}$ was kept constant in each run by adding $\mathrm{HCl}$ or $\mathrm{NaOH}$. Each day, a sub-sample of $15 \mathrm{~mL}$ and 10 to 15 pellets were taken from the culture medium and analyzed for biomass dry weight, reductive sugars, nitrogen $\mathrm{NH}_{4}^{+}-\mathrm{N}, \mathrm{pH}$, microelements and Zeaxanthin concentration.

\subsection{Analytical Methods}

Pellets were separated from $15 \mathrm{~mL}$ culture medium samples and broken with a sterile scalpel. Medium samples, free of pellets, were filtered using Millipore membranes $0.45 \mu \mathrm{m}$ (previously taken to constant weight). The membranes were dried at $90^{\circ} \mathrm{C}$ and biomass determined by dry weight. The liquid filtered was used to measure $\mathrm{NH}_{4}^{+}-\mathrm{N}$ using a modified version of the Kjedahl method [11], total reducing sugars, especially glucose, by dinitrosalicylic acid method [12], $\mathrm{PO}_{4}^{3-}$ [13], $\mathrm{Co}^{2+}, \mathrm{Mg}^{2+}$,
$\mathrm{Mn}^{2+}, \mathrm{Fe}^{2+}$, and $\mathrm{Zn}^{2+}$ by atomic absorption spectroscopy [14]. Some pellets (5 - 6) were broken and suspended in $5-10 \mathrm{~mL}$ of a $1: 1$ mixture of acetone- $\mathrm{NaCl}\left(4.5 \mathrm{~g} \cdot \mathrm{L}^{-1}\right)$. The suspensions were homogenized and allowed to stand for 5 - $10 \mathrm{~min}$. The suspension was then decanted and the supernatant was used to assay Zeaxanthin by UV-visible spectroscopy (Spectronic $21 \mathrm{DUV}$ ) at $450 \mathrm{~nm}$ and $27^{\circ} \mathrm{C}$.

\section{Results and Discussion}

Production of Zeaxanthin was 0.357 to $2.426 \mathrm{~g} \cdot \mathrm{L}^{-1}$ in stirred flasks, using $10 \mathrm{~g} \cdot \mathrm{L}^{-1}$ dextrose, $5 \mathrm{~g} \cdot \mathrm{L}^{-1}$ corn steep liquor, $5 \mathrm{~g} \cdot \mathrm{L}^{-1} \quad \mathrm{NH}_{4} \mathrm{Cl}, 8 \mathrm{~g} \cdot \mathrm{L}^{-1} \quad \mathrm{KH}_{2} \mathrm{PO}_{4}, 1.5 \mathrm{~g} \cdot \mathrm{L}^{-1}$ $\mathrm{MgSO}_{4} \cdot 7 \mathrm{H}_{2} \mathrm{O}, 0.05 \mathrm{M} \mathrm{ZnSO}_{4} \cdot 7 \mathrm{H}_{2} \mathrm{O}, 0.05 \mathrm{M} \mathrm{FeSO}_{4} \cdot 7 \mathrm{H}_{2} \mathrm{O}$, $0.05 \mathrm{M} \mathrm{CoCl}_{2} \cdot 6 \mathrm{H}_{2} \mathrm{O}, 0.01 \mathrm{M} \mathrm{MnSO}_{4} \cdot 7 \mathrm{H}_{2} \mathrm{O}$ and $4.5 \mathrm{~g} \cdot \mathrm{L}^{-1}$ $\mathrm{NaCl}$. The culture medium used for cultivation in a fluidized bed bioreactor was prepared as stated here since all these nutrients were significant, at the levels used, in Zeaxanthin production.

Preliminary experiments showed a Zeaxanthin production $>1.23 \mathrm{~g} \cdot \mathrm{L}^{-1}$ with $1 \mathrm{~mm}$ pellets and $>1.25 \mathrm{~g} \cdot \mathrm{L}^{-1}$ with the $3 \mathrm{~mm}$ ones. Since no significant difference existed, 1 $\mathrm{mm}$ pellets were used for the experimental design. During cultivation in the fluidized bed bioreactor, glucose and $\mathrm{NH}_{4}^{+}-\mathrm{N}$ slowly decreased the first $24 \mathrm{~h}$ and then remained constant at $8.0 \mathrm{~g} \cdot \mathrm{L}^{-1}$ and $2.0 \mathrm{~g} \cdot \mathrm{L}^{-1}$ respectively until $60 \mathrm{~h}$ of cultivation. Biomass had an exponential growth from $0-6 \mathrm{~h}$ and then it has a stationary phase until the end of the experiment $(60 \mathrm{~h})$, with a maximum biomass production of $8.0 \mathrm{~g} \cdot \mathrm{L}^{-1}$. Zeaxanthin production started increasing rapidly when biomass was in the stationary phase and glucose and $\mathrm{NH}_{4}^{+}-\mathrm{N}$ kept constant (around $25 \mathrm{~h}$ ), with a maximum production of $2.96 \mathrm{~g} \cdot \mathrm{L}^{-1}$ at $50 \mathrm{~h}$ of cultivation (Figure 2). The dynamic shown in the fluidized bed bioreactor was similar to that presented

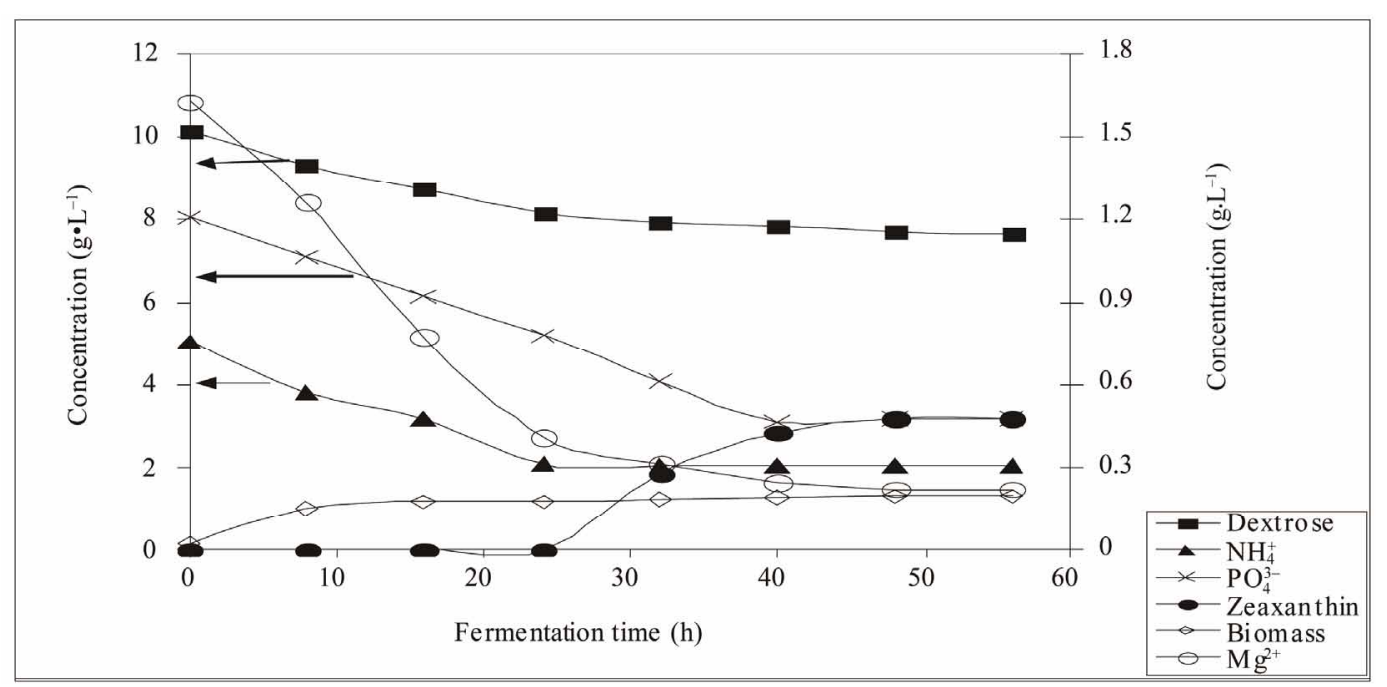

Figure 2. Dynamics of Zeaxanthin $\left(g \cdot L^{-1}\right)$, biomass $\left(g \cdot L^{-1}\right)$, glucose $\left(g \cdot L^{-1}\right), \mathrm{NH}_{4}^{+} \quad\left(g \cdot L^{-1}\right), P_{4}^{3-}$ and $\mathbf{M g}^{2+}$ during the cultivation process. 
by Gierhart [15] in stirred flaks.

In this work, Zeaxanthin production was from 1.25 to $2.96 \mathrm{~g} \cdot \mathrm{L}^{-1}$ (saw Table 2).

Pasamontes et al. [16] reported Zeaxanthin productions of $0.329 \mathrm{~g} \cdot \mathrm{L}^{-1}$ under low concentration of nutrients. The difference in Zeaxanthin production in shake flask and a fluidized bed bioreactor was around $1 \mathrm{~g} \cdot \mathrm{L}^{-1}$ which showed the importance of control of factors in this system.

Air flow, $\mathrm{NaCl}$ addition and control of $\mathrm{pH}$ were the most relevant factors in Zeaxanthin production as indicated by the analysis of variance (Table 3); it decreased $50 \%$ with high air flow. The best results were obtained with a combination of low air flow and high $\mathrm{pH}$ (Figure 3).

Zeaxanthin production was also greatly affected by the addition of sodium chloride. However, the concentration used in the experiments was below that of the natural Flavobacterium habitat: seawater. Response surface analysis showed maximum Zeaxanthin production with 2.96 $\mathrm{g} \cdot \mathrm{L}^{-1}$ increasing as $\mathrm{pH}$ increased (Figure 4). Frequently the initial $\mathrm{pH}$ values, for Zeaxanthin production systems, are reported at around 6.8 and 7.5. However, $\mathrm{pH}$ is not controlled during cultivation time. In this study, the $\mathrm{pH}$ was kept constant. This has been considered a reason for the low Zeaxanthin production reported in literature. The response surface of Zeaxanthin production for changes in temperature and $\mathrm{pH}$ showed a maximum production at $27^{\circ} \mathrm{C}$ and $\mathrm{pH} 7.2$ (Figure 5).

Theoretically, the maximum Zeaxanthin production can be obtained with the following conditions: $\mathrm{C}: \mathrm{N}$ of 2.0, air flow $3 \mathrm{wm}, \mathrm{NaCl} 4.5 \mathrm{~g} \cdot \mathrm{L}^{-1}$ and $\mathrm{pH}$ 7.2. As shown

Table 3. Analysis of variance for Zeaxanthin production in a fluidized bed bioreactor with immobilized Flavobacterium sp cells.

\begin{tabular}{cccccc}
\hline Factor & Sum of squares & Degree freedom & Mean square & $\mathbf{F}_{\mathbf{0}}$ & Pr $>$ F \\
\hline Air flow & 2.4410 & 1 & 2.4410 & 28.0722 & 0.0007 \\
$\mathrm{pH}$ & 1.5688 & 1 & 1.5688 & 18.0382 & 0.0028 \\
Temperature & 0.0518 & 1 & 0.0518 & 0.5951 & 0.4626 \\
Bead diameter & 0.1743 & 1 & 0.1743 & 2.0042 & 0.1946 \\
Inoculum-medium ratio & 0.2678 & 1 & 0.2678 & 3.0793 & 0.1173 \\
Natural light & 0.0473 & 1 & 0.0473 & 0.5440 & 0.4818 \\
NaCl & 1.7226 & 1 & 1.7226 & 19.8078 & 0.0021 \\
Residual & 0.6958 & 8 & 0.6958 & & \\
\hline
\end{tabular}

P significance level of 0.05 .

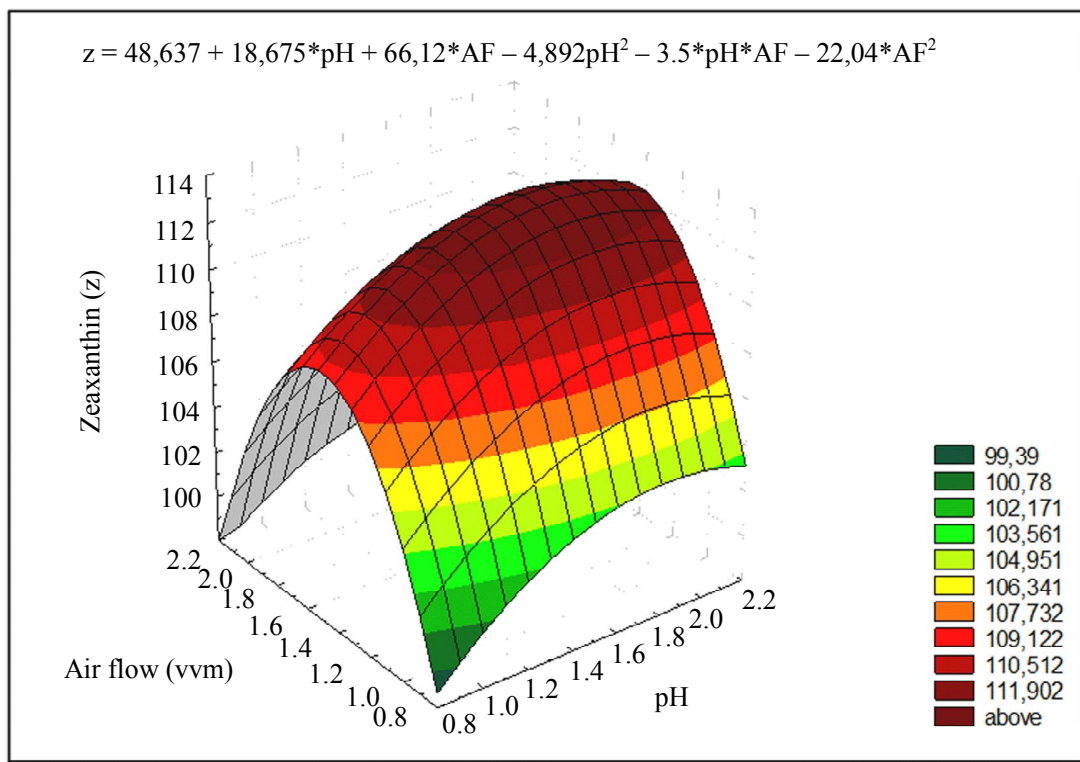

Figure 3. Response surface of air flow and $\mathrm{pH}$ in Zeaxanthin production $\left(\mathrm{g} \cdot \mathrm{L}^{-1}\right)$. Zeaxanthin production can be calculated as function of air flux and $\mathrm{pH}$, for the mentioned experimental conditions, with a significance level of 0.05 and a statistical confidence of $95 \%$. 


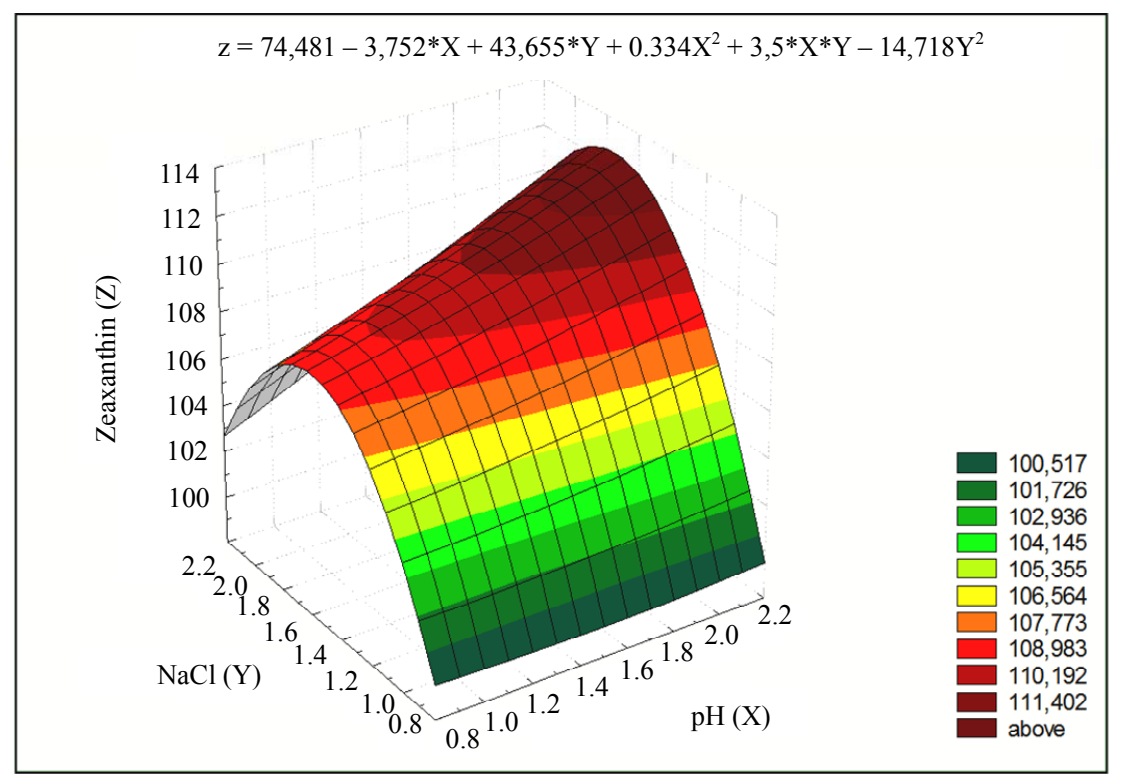

Figure 4. Response surface of Zeaxanthin production $\left(\mathrm{g} \cdot \mathrm{L}^{-1}\right)$ for changes of $\mathbf{p H}$ and saline solution. Zeaxanthin production can be calculated as a function of $\mathbf{p H}$ and saline solution with a significance level of 0.05 and a statistical confidence of $95 \%$.

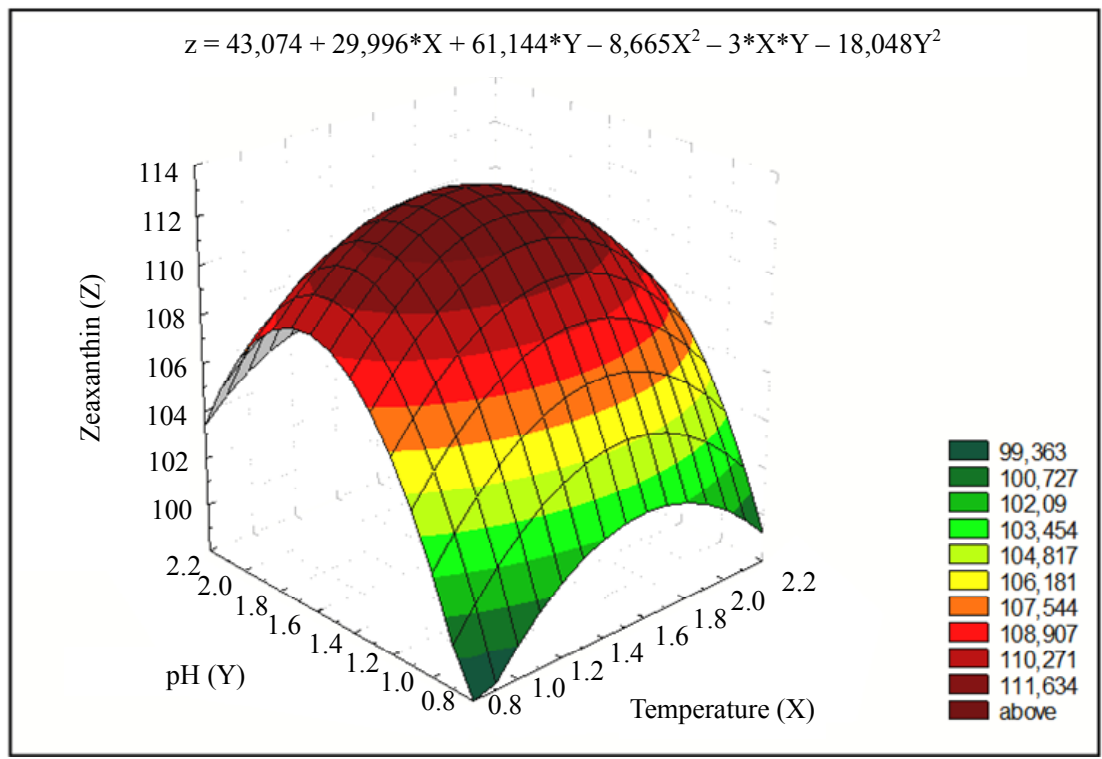

Figure 5. Response surface of Zeaxanthin production $\left(\mathrm{g} \cdot \mathrm{L}^{-1}\right)$ for changes of temperature and pH. Zeaxanthin production can be calculated as function of temperature and $\mathrm{pH}$ with a significance level of 0.05 and a statistical confidence of $95 \%$.

in Table 2, Zeaxanthin production was calculated with a predictive equation using the values of a maximum production [9]:

$$
Y=Y_{t}+\left(A-Y_{t}\right)+\left(B-Y_{t}\right)+\left(C-Y_{t}\right)+\left(D-Y_{t}\right)
$$

where $Y$ is the estimated Zeaxanthin production, $Y_{t}$ is the experimental mean of Zeaxanthin given for all the experiments, and $A$ ( $C: \mathrm{N}$ ratio), $B$ (air flow), $C(\mathrm{NaCl})$, and $D(\mathrm{pH})$. These factors presented the greatest effect in Zeaxanthin production. Values for the highest production were C:N 2.0, air flow $3 \mathrm{vvm}, 4.5 \mathrm{~g} \cdot \mathrm{L}^{-1} \mathrm{NaCl}$ y $\mathrm{pH} 7.2$.
The equation predicts a concentration of $3.18 \mathrm{~g} \cdot \mathrm{L}^{-1}$. The experiment was done in duplicate.

\section{Conclusion}

Experimental orthogonal $\mathrm{L}_{18}$ design enabled the best composition of culture medium to be found where a concentration of Zeaxanthin of $2.46 \mathrm{~g} \cdot \mathrm{L}^{-1}$ was obtained; in a shake flask, which, according to literature, had never previously been obtained. Optimal conditions of the cultivation process in fluidized bioreactor enabled the maximum yield of Zeaxanthin production to be obtained; 3.16 
$\mathrm{g} \cdot \mathrm{L}^{-1}$, approximately 10 times greater than the value reported to date in literature. The analysis of variance showed that airflow, saline solution and $\mathrm{pH}$ were the parameters that most affected the biosyntheses of Zeaxanthin.

\section{Acknowledgements}

This research was funded by Dirección General de Educación Superior Tecnológica (DGEST 4258.11-P).

\section{REFERENCES}

[1] E. A. Johnson and W. A. Schroeder, "Microbial Carotenoids," In: A. Fiechter, Ed., Advances in Biochemical Engineering/Biotechnology, Springer, Berlin Heidelberg, New York, 1995, pp. 119-178.

[2] G. Sandmann, M. Albrecht, G. Schnurr, O. Knörzer and P. Böger, "The Biotechnological Potencial and Design of Novel Carotenoids by Gene Combination in Escherichia coli," Trends in Biotechnology, Vol. 17, No. 6, 1999, pp. 233-237. doi:10.1016/S0167-7799(99)01307-4

[3] A. Mortensen and L. H. Skibsted, "Kinetics and Mechanism of the Primary Steps of Degradation of Carotenoids by Acid in Homogeneous Solution," Journal of Agricultural and Food Chemistry, Vol. 48, No. 2, 2000, pp. 279-286. doi:10.1021/jf9904620

[4] D. Mc Namara, "Los Beneficios Nutritivos Adicionales del Huevo," Centro de Nutrición del Huevo, Washington DC, Vol. 29, 2002, pp. 1-3.

[5] E. Schafer and D. Nelson, "El Valor Saludable de las Frutas y Verduras," 2001. http://www.extension.iastate.edu/pubs

[6] M. Albrecht, N. Misawa and G. Sandmann, "Metabolic Engineering of the Terpenoid Biosynthetic Pathway of Escherichia coli for Production of the Carotenoids BetaCarotene and Zeaxanthin," Biotechnology Letters, Vol. 21, No. 9, 1999, pp. 791-795.

[7] L. Bohlin, U. Göransson, C. Alsmark, C. Wedén and A.
Backlund, "Natural Products in Modern Life Science," Phytochemistry Reviews, Vol. 2, 2010, pp. 279-301. doi:10.1007/s11101-009-9160-6

[8] M. C. Montes and I. Magaña, “ $\Delta$ '-Dehydrogenation of Steroids by Arthrobacter simplex Immobilized in Calcium Polygalacturonate Beads," Journal of Industrial Microbioliology and Biotechnology, Vol. 8, No. 4, 1991, pp. 259-264. doi:10.1007/BF01576064

[9] Y. Wu and M. W. Hobbs, "Quality Engineering: Product \& Process Design Optimization," American Supplier Institute Inc., Derbon, 1987.

[10] G. S. Peace, "Taguchi Methods: A Hands-On Approach," Addison-Wesley Publishing Company, Inc., Boston, 1993.

[11] AOAC, "Official Methods of Analysis," 15th Edition, Association of Official Analytical Chemists, Arlington, 1990.

[12] G. L. Miller, "Use of Dinitrosalicylic Acid Reagent for Determination of Reducing Sugars," Analytical Chemistry, Vol. 31, 1959, pp. 426-428. doi:10.1021/ac60147a030

[13] AASGP Committee Report, "The Determination of Orthophosphate, Hydrolyzable Phosphate, and Total Phosphate in Surface Waters," Journal of American Water Works Association, Vol. 50, No. 12, 1958, pp. 1563-1574. http://www.jstor.org/stable/41255060

[14] Environmental Monitoring and Support Laboratory, "Methods for Chemical Analysis of Water and Wastes," Office of Research and Development US Environmental Protection Agency, Cincinnati, 1979.

[15] D. L. Gierhart and M. R. High, "Production of Zeaxanthin and Zeaxanthin: Containing Compositions," US Patent No. 5308759, 1994.

[16] L. Pasamontes, H. Denis, M. Tessier, H. P. Hohmann, J. Schierle and A. P. G. M. van Loon, "Isolation and Characterization of the Carotenoid Biosynthesis Genes of Flavobacterium sp. Strain R1534," Journal of Gene, Vol. 185, No. 1, 1997, pp. 35-41. doi:10.1016/S0378-1119(96)00624-5 